\title{
Spontaneous pulmonary hernia secondary to intercostal muscle tear
}

\author{
Anne M O' Mahony @ (1) ${ }^{1}$ Kevin M Murphy, ${ }^{2}$ Terence M O'Connor, ${ }^{1}$ David R Curran ${ }^{1}$
}

${ }^{1}$ Respiratory Medicine, Mercy University Hospital, Cork, Ireland ${ }^{2}$ Radiology, Mercy University Hospital, Cork, Ireland

Correspondence to Dr Anne M O' Mahony; anneomahony.aom@gmail.com

Accepted 26 September 2019

\section{DESCRIPTION}

Pulmonary hernia refers to the protrusion of pulmonary parenchyma with pleural membranes through a defect in the thoracic wall. It was originally described in 1499 by Ronald iand in 1847 , Morel-Lavelle classified pulmonary hernias as either congenital or acquired. ${ }^{1}$ The majority $(80 \%)$ of acquired hernias occur as a consequence of trauma. ${ }^{2}$ Spontaneous pulmonary hernia (SPH) due to coughing is a result of the associated increased intrathoracic pressure and is common in patients with asthma or chronic obstructive pulmonary disease in the setting of hyperinflation and possible long-term steroid therapy. The role for surgical repair is controversial, but indications for surgical intervention include increasing size, refractory pain or incarceration. ${ }^{3}$ However, the majority of cases follow a benign course and can be managed conservatively.

Herein, we describe a case of SPH managed conservatively and report the use of ultrasonography (US) in identifying the thoracic wall defect.

A 65 -year-old man with a history of asthma presented with a 1-week history of cough productive of purulent sputum, increasing dyspnoea and wheeze. The day prior to presentation, he had haemoptysis and developed severe left pleuritic chest pain. His vitals were stable at presentation, and auscultation of his lung fields revealed diffuse

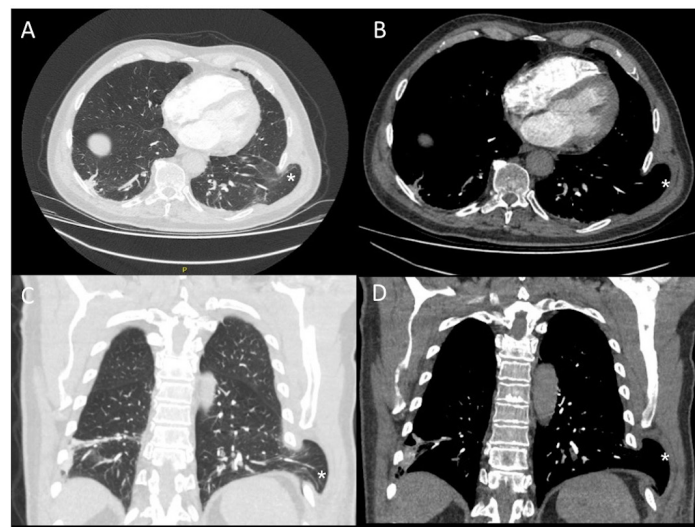

Figure $1 \mathrm{CT}$ of thorax with contrast demonstrating widening posterolaterally of the intercostal space between the left eighth and ninth ribs at the costophrenic angle and herniation of the pleura and lung between the ribs on axial views $(A, B$, asterisk) and into the chest wall, deep to the oblique muscles, serratus anterior and latissimus dorsi on coronal views ( $C, D$, asterisk). Bibasal atelectasis, scarring, diffuse bronchial wall thickening and endobronchial plugging are present in the lower lobes. $\mathrm{P}$, posterior

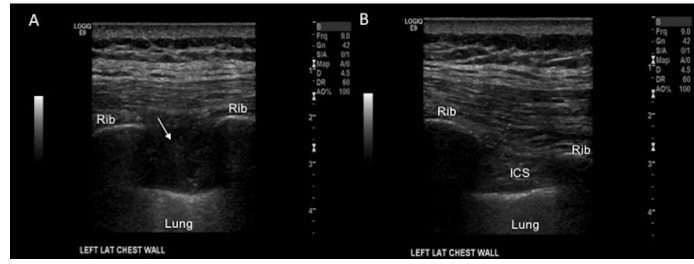

Figure 2 On US of the chest wall, the hernia is reduced $(A, B)$. A tear in the intercostal muscles is seen $(A)$, confirming the cause of the pulmonary hernia. This is demonstrated by enlargement of the intercostal gap and the presence of a hypoechoic and disorganised muscle (A, arrow). (B) In comparison, the normal appearance of an ICS and intercostal muscle on US is illustrated. ICS, intercostal space; US, ultrasonography.

\section{Learning points}

- Spontaneous pulmonary hernia is rare but should be considered in the differential diagnosis in a patient with vigorous coughing and pleuritic chest pain with unremarkable chest radiograph

- Diagnosis can be confirmed with chest CT, but ultrasonography is a useful, cheap and ubiquitous tool that can assist in confirming the defect.

- Management is usually conservative.

expiratory wheeze. Chest radiograph showed evidence of hyperinflation with no consolidation. His D-dimer was elevated at $1.99 \mathrm{mg} / \mathrm{L}$ (0-0.5 mg/L).

He proceeded to CT pulmonary angiogram, which showed no evidence of pulmonary embolism and demonstrated a pulmonary hernia, protruding at the eighth intercostal space (figure 1A-D). US of the chest wall located a tear in the intercostal muscles (figure 2A), identified by the slightly enlarged intercostal space and hypoechoic and disorganised muscle (arrow, figure 2A), as compared with a normal seventh intercostal space (figure 2B). No protrusion of underlying lung tissue was seen as the pulmonary hernia had reduced. The patient was managed conservatively and treated with antibiotics, steroids and nebulised bronchodilators for his infective exacerbation. He was asymptomatic at 6 weeks' follow-up.

Contributors AMOM, KMM, TMOC and DRC: planning, conception and design of the paper. KMM: imaging interpretation 


\section{Images in...}

and supply of images. AMOM: final draft preparation. DRC: review of the draft and supervision of the paper.

Funding The authors have not declared a specific grant for this research from any funding agency in the public, commercial or not-for-profit sectors.

Competing interests None declared.

Patient consent for publication Next of kin consent obtained.

Provenance and peer review Not commissioned; externally peer reviewed.
ORCID ID

Anne M O' Mahony http://orcid.org/0000-0002-4188-5912

\section{REFERENCES}

1 Donato AT, Hipona FA, Navani S. Spontaneous lung hernia. Chest 1973;64:254-6.

2 Morel-Lavallée A. Hernies Du poumon. Bull Soc Chir Paris 1845-1847;1:75-195.

3 Ross RT, Burnett CM. Atraumatic lung hernia. Ann Thorac Surg 1999;67:1496-7.

Copyright 2019 BMJ Publishing Group. All rights reserved. For permission to reuse any of this content visit https://www.bmj.com/company/products-services/rights-and-licensing/permissions/

BMJ Case Report Fellows may re-use this article for personal use and teaching without any further permission.

Become a Fellow of BMJ Case Reports today and you can:

- Submit as many cases as you like

- Enjoy fast sympathetic peer review and rapid publication of accepted articles

Access all the published articles

Re-use any of the published material for personal use and teaching without further permission

\section{Customer Service}

If you have any further queries about your subscription, please contact our customer services team on +44 (0) 2071111105 or via email at support@bmj.com.

Visit casereports.bmj.com for more articles like this and to become a Fellow 